\title{
Bank Opacity and Crash Risk
}

\author{
Yuan Wen ${ }^{1}$ \\ ${ }^{1}$ State University of New York at New Paltz, USA \\ Correspondence: Yuan Wen, State University of New York at New Paltz, USA.
}

Received: September 5, 2015

Accepted: February 15, 2016

Online Published: May 16, 2016

doi:10.5430/afr.v5n2p138

URL: http://dx.doi.org/10.5430/afr.v5n2p138

\begin{abstract}
Banks are considered more opaque than non-bank firms. We examine how bank assets opacity affects bank crash risk, using loans and trading assets (both measured as a percentage of total assets) as proxies for opacity. We find that opacity of assets is positively related to bank crash risk. In addition, we investigate how CEO compensation affects bank crash risk since equity-based pay is blamed for motivating CEOs to engage in opportunistic behaviors. However, we do not find evidence supporting the view that CEO equity-based pay is associated with higher crash risk. Our results are robust to different specifications and measures of crash risk.
\end{abstract}

Keywords: Opacity, Crash Risk, CEO Compensation

\section{Introduction}

Opacity is the lack of transparency that outside investors face in their attempts to assess the intrinsic value of a firm. For bank as well as non-bank firms, opacity could arise for the following reasons. First of all, mangers have incentives to hoard negative news or disclose misleading information with the purpose, for example, of maximizing their compensation, increasing the value of their equity holdings (Cheng and Warfield 2005), lowering the cost of external financing (Dechow et al. 1996), or beating analysts' forecasts (Degeorge et al. 1999). Secondly, outside investors, who have little information about the integrity of a company's information disclosure, may interpret the quality and credibility of the disclosed information in contradictory ways (Jones et al., 2013). Thirdly, even if information disclosed is credible and full, investors may not have the knowledge and skills to understand the profitability and risks due to the complexity of the business (Jones et al., 2013).

Banks are considered more opaque than non-bank firms because outside investors have little information about the risks involved in financial intermediation (Ross, 1989). Among all assets classes, loans and trading assets are considered the major source of opacity for banks (Morgan, 2002, Flannery, Kwan and Nimalendran, 2004). Banks have privileged information regarding the credit quality of the borrowers and the characteristics of the loan contracts while outside investors do not have access to such information. It follows that a larger share of loans in total assets is associated with greater opacity of the bank. A bank's position in trading assets is public information that is disclosed periodically. However, trading assets change so fast (Morgan 2002) that it is difficult to tell what trading activities occur and how the bank's position in trading assets changes between two reporting dates. Furthermore, some trading assets such as derivatives and mortgage-backed assets are inherently complex, which makes it difficult for outside investors to estimate their risk and return. The opaque nature of banks makes them vulnerable to bank runs and contagion.

We examine the impact of bank opacity on stock crash risk. Crash occurs when previously concealed negative news surfaces and leads to a sudden drastic stock price decline. Like any other managers, a bank manager has incentives to hoard negative news. Jin and Myers (2006) and Bleck and Liu (2007) suggest that there is a threshold on the amount of bad news a manager can accumulate without disclosing it to the outsiders. When the threshold is reached, the bad news will surface all at one. The complexity and opaque nature of bank assets can make it difficult for the investors to understand the risks embedded in the bank's business, exacerbating the opacity caused by news hoarding and increasing the crash risk. When the accumulated bad news is eventually uncovered and understood by the investors, there could be a stock price crash (Jin and Myers, 2006, Bleck and Liu, 2007). The stock price crash of a bank has a systematic impact on the overall economy because banks have a wide spectrum of business counterparties and contagions between banks are often observed. We look at the source of bank opacity and examine whether they lead to a higher crash risk. Specifically, we investigate the two major source of opacity - loans and trading assets and their relationship with crash risk. 
Since the financial crisis in 2007-2009, investors, media, researchers and regulators have increasingly focused attention on the incentives provided by equity-based managerial compensations. It is believed by some that a managerial compensation scheme heavily weighted towards equity (stock options in particular), gives managers incentives to engage in activities that help to inflate stock price for the short term at the cost of long term performance (Bebchuk, 2009). Benmelech, Kandel and Veronesi (2010)'s theoretical model suggest that equity-based compensation gives managers incentives to hoard negative news about future growth options. Such negative news hoarding, while serving to maintain a high stock price for the short term, can lead to severe overvaluation and eventually lead to a stock price crash. Furthermore, Benmelech, Kandel and Veronesi (2010) conjecture that when firm growth slows down and the CEO wants to conceal this, she will choose to engage in negative-NPV projects. The subprime investment policies will eventually lead to a crash of stock price.

However, Fahlenbrach and Stulz (2011) have a different view on managerial compensation. They argue that in an efficient stock market, a bank's long term performance is reflected in its stock price. Therefore, it is in the best interest of the CEO to improve the long term performance of her firm rather than focusing on the short term performance if she has equity stakes in the company. Therefore, incentives from equity based compensation should not lead to a higher crash risk.

To investigate whether equity-based pay increases crash risk, we use the incentive ratios created by Bergstresser and Philippon's (2006) to measure the strength of incentives provided by CEO's stock holdings and option holdings.

Using a sample of 6619 bank holding company (BHC)-years from 1986 to 2013, we find that a larger share of loans in total assets is associated with higher crash risk. The results are robust to different measures of crash risk and different regression model specifications. We also find that BHCs with more trading assets tend to have higher crash risk, although the evidence is weaker than that for loans. Our results suggest that loans and trading assets contribute to greater opacity for BHCs and such opacity leads to higher crash risk. Consistent with Fahlenbrach and Stulz (2011), we find equity incentive to be insignificantly associated with crash risk, suggesting that equity-based pay does not lead to significantly more short-termism activities such as negative news hoarding.

To the best of our knowledge, this is the first study that examines the relationship between bank assets opacity and crash risk using U.S. Bank data. A few papers look at how opacity affects crash risk for non-financial firms or the universe of firms (for example, Hutton et al., 2009). However, no paper to date examines bank assets opacity and its relationship with opacity risk. Given that bank opacity is unique and a crash of bank stocks has a systematic impact on the overall market, it is important to fill the void by investigating the role of bank assets opacity in affecting crash risk.

Equity-based compensation, while initially designed to align the interest of the managers with that of the shareholders, has been blamed for inducing managers to engage in short-termism behaviors. And for this reason, equity-based compensation, especially stock options, has been considered one of the causes of the financial crisis in 2007-2009 by some researchers, shareholder activists, and regulators. However, there is no empirical evidence showing that equity-based compensation leads to the financial crisis. Kim et al. (2011) examine firms in the ExecutiveComp database and find only a weak link between CEO option incentives and crash risk. There is no paper to date that examines the relationship between CEO compensation and BHCs crash risk.

Our study has important policy implications. First, our findings that assets opacity increases crash risk for banks points to the fact that enhancing the transparency of banks remains an important task for regulators. Since loans and trading assets increase crash risk for banks, it is important that regulators require banks to increase the reporting frequency of trading assets and/or to disclose more information about the quality of its loans. Secondly, equity-based pay has been blamed for the financial crisis by academics, media, shareholder activist and regulators (e.g., Bebchuck, 2009). The "Say on pay" rule that gives shareholders the right to vote on the compensation of executives is the regulator's solution to curb excessive executive pay and unreasonable pay structure. Our finding that equity incentives are not associated with higher crash risk suggests that such blame is not well grounded. Therefore, in their endeavor to reform executive pay in the US, regulators and shareholder activists should bear in mind that equity-based pay is not the culprit in the crisis.

\subsection{Opaqueness of banks}

Loans are considered a primary source of opacity for banks. Bank loans are privately negotiated between a bank (or multiple banks) and a borrower. Banks have private information about the creditworthiness of the clients and the terms of the contracts that outsiders do not have, leading to information asymmetry between bank managers and outsiders. Morgan (2002) finds that Moody's and S\&P have greater disagreement over bank debt than non- bank 
debt and that loans increase the likelihood of such disagreement, suggesting that loans represent a major source of opacity for banks. Jones et al. (2013) find that banks with a larger share of loans in total assets tend to have higher valuation discount and the stock returns of these banks tend to have greater synchronicity with the market, suggesting that loans increase opacity for banks.

Trading assets mainly consist of financial securities and derivatives that banks hold for the purpose of reselling in the near future for a profit. Trading assets are transparent in the sense that a bank's position in trading assets is made public through the bank's quarterly reports. However, between two reporting dates, the bank's position in trading assets can change drastically, making it difficult for outsiders to track and monitor such assets. Furthermore, some trading assets are inherently complex and difficult to value (Morgan, 2002, Jones et al., 2013). Even with full and accurate information, it can still be difficult for outsiders to understand the profitability and risks for these assets. The worst situation occurs when markets cease to function properly as happened in the financial crisis in 2007 and trading assets become illiquid (Jones et al., 2012). Accounting rules (FASB statement 157) require that trading assets are recorded as market-to-market on the balance sheet, thereby adjusting to the current market value. Under such rules, the market value of trading assets is determined by that of similar securities that are traded in the market. When market dries up, it becomes difficult to estimate the intrinsic value of these assets based on observed market prices (Jones et al., 2012).

In addition, bank managers' incentive to hoard negative news can be stronger than that of their non-bank counterparts. In regulated industries such as banking, managers may hoard negative news in order to avoid lawsuits based on "prudent man laws", to escape negative announcements and disciplinary actions from regulators subsequent to bank examinations, and to reduce the chances of denial of their applications for geographic/product expansions and mergers and acquisitions (M\&As) by the regulators. Additional motivations driving negative news hoarding by banks include avoiding the loss of major clients for guarantee services such as standby letters of credit, loan commitments, and counter-party positions in derivatives, and passing the regulatory tests of capital adequacy and Community Reinvestment Act (CRA). All the above mentioned factors lead to an informational environment that is lack of transparency and informativeness.

\section{Hypothesis}

Loans are customized, privately negotiated and illiquid. Despite increases in information availability and trading activities, the risk of bank loans is still very difficult to evaluate or manage (Greenspan 1996). It follows that loans are major contributors to bank opacity. Therefore, we hypothesize

H1: BHCs with higher shares of loans in total assets have higher crash risk

Trading assets are considered another major source of bank opacity. First, the intrinsic complexity of some trading assets makes it difficult for outside investors to value these assets. Second, trading assets are usually very liquid. Banks change their positions in trading assets frequently. Even if banks report their trading assets periodically as required by regulations, it is difficult for outside investors to monitor the trading activities between two reporting dates. Furthermore, given that trading assets are difficult to value or monitor, they are prone to management manipulations (Jones et al., 2012). Therefore, we hypothesize as follows

$\mathrm{H} 2$ : BHCs with higher share of trading assets in total assets have higher crash risk.

There are a lot of controversies regarding the role of managerial compensation in corporate governance. It is believed by some that equity-based compensation gives managers incentives to engage in myopic activities that help to inflate stock price for the short term(e.g., Bebchuck, 2009). One of these activities is negative news hoarding (Benmelech, Kandel and Veronesi, 2010). A result of negative news hoarding is overvaluation of stock which could eventually lead to a crash. An alternative view is that in an efficient stock market, a bank's long term performance is reflected in its stock price. CEOs with equity holdings will be hurt by weak long term performance. Therefore, it is in the best interest of the CEO to improve long term performance instead of sacrificing it to inflate short term performance (Fahlenbrach and Stulz, 2011). Therefore, equity-based pay should not motivate short-termism activities such as news hoarding because these activities will hurt long term firm performance. Hence:

H3: Incentives from CEO equity holdings are positively related to crash risk.

\section{Sample and Variable Construction}

\subsection{The Sample}

We obtain data related to bank assets from the Bank Regulatory Database (FRY-9) for the period beginning in 1986 and ending in 2013. The BHC section of the Bank Regulatory Database, maintained by the Federal Reserve Bank of 
Chicago, collects financial data from BHCs included in the FRY-9 call reports. These reports contain assets, loans, loan loss provisions and other financial statement information for large U.S. BHCs. We start with all the BHCs in the database. We could find 169,169 observations for the period 1986 to 2013 . We match these BHC years to CRSP and Compustat and obtain 10,950 observations. Among these 10,950 observations, 6,619 have complete data for our main regression (Equation 10). We define these 6,619 observations as our initial sample. ExecutiveComp provides data on CEO compensations. However, this database does not include all the BHCs in our initial sample. Therefore, we look at the impact of CEO equity incentives on crash risk (Equation 11) only for the BHCs that are included in both our initial sample and the ExecutiveComp database. We are able to compute equity incentive and examine its impact on crash risk for 1,273 observations.

\subsection{Variable Construction}

We examine loans and trading assets as two major sources of bank opacity. One of our main independent variable LOAN is the value of loans (FRY-9C BHCK2122-BHCK2123) as a percentage of total assets (FRY-9C BHCK2170). The other main independent variable TRADING is the value of trading assets (FRY-9C BHCK3545) as a percentage of total assets.

We use 5 different measures of crash risk. Our measures of crash risk are based on firm-specific stock returns which are measured from the residual of the following regression (Hutton et al., 2009, Bradshaw et al., 2010):

$$
R_{j, t}=\alpha_{j}+\beta_{1, j} R_{m, t-1}+\beta_{2, j} R_{i, t-1}+\beta_{3, j} R_{m, t}+\beta_{4, j} R_{i, t}+\beta_{5, j} R_{m, t+1}+\beta_{6, j} R_{i, t+1}+\varepsilon_{j, t}
$$

Where $R j, t$ is the stock return for firm $j$ in week $t, R_{m, t}$ is the return for the value-weighted market index from CRSP for week $t . R_{i, t}$ is the return for the value-weighted industry index calculated from all BHCs for week $t$. The lead and lag terms of market returns and industry returns are included to allow for nonsynchronous trading (Dimson, 1979). Firm specific return is defined as the log of 1 plus the residual return from equation 1 . By using the residual from the above regression, we filter out market-wide crash risk to focus on cross-sectional variation in BHCs crash risk (Bradshaw et al., 2010).

The first measure - CRASH, is an indicator variable that equals 1 if during a specific year, the BHC experienced at least one firm-specific weekly return falling 3.09 standard deviations below the mean of all weekly firm-specific returns for that year (Hutton et al., 2009).

Our second measure - EXTRASIGMA, tells us to what extent the worst weekly return of a year falls below the mean weekly return of that year. To be more specific, EXTRASIGMA measures by how many standard deviations the worst weekly return falls below the mean weekly return (Hutton et al., 2009). EXTRASIGMA is measured as:

EXTRASIGMA =

$$
\text { -Min }\left[\frac{\text { Firm-specific weekly return-mean of firm-specific weekly return }}{\text { standard deviation of firm-specific weekly return }}\right]
$$

Our third measure-NCSKEW, is measured as the inverse of the third central moment of firm-specific weekly return scaled by the variance of firm-specific weekly return raised to 3/2 ( Kim et al., 2011a, 2011b).

$$
\text { NCSKEW }=-\left[\mathrm{n}(\mathrm{n}-1)^{3 / 2} \sum_{T=1}^{n}\left(w_{i, T, t}-\bar{w}_{i, t}\right)^{3}\right] /\left[(\mathrm{n}-1)(\mathrm{n}-2)\left(\sum_{T=1}^{n}\left(w_{i, T, t}-\bar{w}_{i, t}\right)^{2}\right)^{3 / 2}\right]
$$

Where $w_{i, T, t}$ is the firm-specific weekly stock return for week T in year t. $\bar{w}_{i, t}$ is the mean firm-specific weekly stock return for year $\mathrm{t}$ and $\mathrm{n}$ is the number of weeks for year $\mathrm{t}$. We put a negative sign in front of the skewness so that a higher NCSKEW corresponds to a more negative-skewed stock return distribution, namely, higher crash risk.

Our fourth measure - DUVOLT, is measured as

DUVOLT $=$

$$
\log \left[\frac{\text { standard deviation of weekly returns for down weeks }}{\text { standard deviation of weekly returns for up weeks }}\right]
$$

An up (down) week is defined as a week when the firm-specific weekly return is above (below) the annual mean (Chen et al., 2001).

Our fifth measure -COUNT is based on the number of crashes and the number of jumps during a year. A crash (jump) occurs when the firm-specific weekly return falls 3.09 standard deviation below (above) the annual mean. COUNT is defined as the number of crashes minus the number of jumps for the year (An and Zhang, 2013, Jin and Myers, 2006). 
We use the incentive ratio created by Bergstresser and Philippon (2006) to measure the strength of CEO equity incentives. We use the dividend adjusted Black-Scholes model to calculate the incentive ratio. The dividend adjusted Black-Scholes model measures option value as

$$
\omega=S^{-\delta T} N\left(d_{1}\right)-X e^{-\delta T} N\left(d_{2}\right)
$$

Where $\mathrm{d} 1=\left[\operatorname{In}(S / X)+\left(r-\delta+\sigma^{2} / 2\right) T\right] / \sigma T^{1 / 2} \delta$ is the expected dividend rate, $\mathrm{T}$ is the time to maturity of the option expressed as the number of years, $\mathrm{S}$ is the stock price at the valuation date, $\mathrm{X}$ is the strike price of the option. $N$ is the standard normal cumulative distribution function.

$$
\text { Delta }=\mathrm{e}^{-\delta \mathrm{T}} \mathrm{N}\left(\mathrm{d}_{1}\right)
$$

The dollar change in option value in reaction to a $1 \%$ change in stock price (referred to as ONEPCT hereafter) is estimated as

$$
\text { ONEPCT }=\text { Delta } * S * \text { number of options } / 100
$$

The incentive ratio for options (INCENTIVE_OPT) is measured as:

$$
\text { INCENTIVE_OPT }=\text { ONEPCT/ }(O N E P C T+S A L A R Y+B O N U S)
$$

The incentive ratio for stock holdings (INCENTIVE_STK) is measured similarly to INCENTIVE_OPT, except for the fact that the delta for stock holdings is 1.

Following Core and Guay (2002), we use the end-of-fiscal-year price as the price of the underlying stock at the time of the grant (PRCC_F from Compustat). Expected dividend rate is measured as 3-year average dividend (BS-YIELD from Compustat). $\sigma$ is the annualized standard deviation of monthly stock returns over the 60 months preceding the sample year. The strike price and expiration date for options granted in previous years are not directly available. Following Core and Guay (2002), we compute the strike price for these options as follows:

Strike price $=$

$$
\begin{array}{r}
\text { stock price - }[(\text { OPT_UNEX_UNEXER_EST_VAL+ OPT_UNEX-EXER_EST_VAL)/ (OPT_UNEX_EXER_NUM } \\
\text { + OPT_UNEX_UNEXER_NUM)] }
\end{array}
$$

where OPT_UNEX_UNEXER_EST_VAL is the value of unexercised unexercisable options from ExecutiveComp, OPT_UNEX_EXER_EST_VAL is the value of unexercised exercisable options, OPT_UNEX_UNEXER_NUM is the number of unexercised unexercisable options and OPT_UNEX_EXER_NUM is the number of unexercised exercisable options

Summary statistics are reported in Table 1.

Table 1. Descriptive statistics

CRASH, EXTRASIGMA, NCSKEW, DUVOLT and COUNT are measures of crash risk. MTB is the market to book ratio. LOAN is the value of loans and TRADING is the value of trading assets, both expressed as a percentage of total assets. RET is lagged stock return and SIGMA is the standard deviation of past stock returns. CAPITAL is the capital ratio. OFFBSRISK is noninterest income divided by total interest income. OPT_INCENTIE is incentive ratio for options. STK_INCENTIVE is incentive ratio for stock holdings.

\begin{tabular}{lllll}
\hline & Mean & Median & Minimum & Maximum \\
\hline SIZE & 14.3288 & 13.97242 & 11.17872 & 21.55942 \\
MTB & 1.6173 & 1.4843 & .2493 & 4.3983 \\
CAPITAL & .0899 & .0853 & .0422 & .1911 \\
TRADE & .0049 & 0 & 0 & .1393 \\
LOAN & .6426 & .6588 & .2192 & .8734 \\
OFFBSRISK & .2702 & .1460 & .0157 & 1.5290 \\
SIGMA & .0505 & .0395 & .0122 & .1608 \\
RET & .0016 & .0012 & -.0186 & .0197 \\
CRASH & .2619 & 0 & 0 & 1 \\
EXTRASIGMA & 2.8883 & 2.5015 & 1.2773 & 6.8182 \\
NCSKEW & .3013 & -.0669 & -2.7225 & 6.4208 \\
DUVOLT & .1162 & -.0833 & -2.1461 & 4.3501 \\
COUNT & -.1697 & 0 & -3 & 1 \\
OPT_INCENTIE & .2260 & .1719 & 0 & .8724 \\
STK_INCENTIVE & .1467 & .0706 & 0 & .9799 \\
\hline
\end{tabular}




\section{Empirical Results}

\subsection{Main Regression}

Our main specification is

CRASHRISK $_{t}$

$$
\begin{array}{r}
=\beta_{0}+\beta_{1} \text { Size }_{t-1}+\beta_{2} \text { MTB }_{t-1}+\beta_{3} \text { ROA }_{t}+\beta_{4} L_{O A N_{t}}+\beta_{5} \text { TRADING }_{t}+\beta_{6} \text { SIGMA }_{t-1}+\beta_{7} \text { RET }_{t-1}+\beta_{8} \text { CAPITAL }_{t}+ \\
\beta_{9} \text { OFFBSRISK } \\
t
\end{array}
$$

Where CRASHRISK are the 5 measures of crash risk described in section 4.2-CRASH, EXTRASIGMA, NCSKEW, DUVOLT and COUNT. Size is the log of total assets. MTB is the market to book ratio. ROA is the return on assets. LOAN is the value of total loans as a percentage of total assets, TRADING is the value of trading assets as a percentage of total assets. Following Kim et al. (2011), we include lagged stock return (RET) and the standard deviation of past stock returns (SIGMA) as control variables. CAPITAL is the capital ratio measured as 1 minus the ratio of total liabilities and minority interest (FRY-9C BHCK 2948) to total assets. OFFBSRISK is off-balance sheet risk measured as total noninterest income (FRY-9C BHCK4079) divided by total interest income (FRY-9C BHCK4107). FF is firm fixed effect. YF is year fixed effect. We use firm fixed effects to control for unobservable firm characteristics which likely affect the assets mix.

\begin{tabular}{|c|c|c|c|c|c|}
\hline & CRASH & EXTRASIGMA & NCSKEW & DUVOLT & COUNT \\
\hline SIZE & $0.0489 * *$ & $0.1522 * *$ & $0.2153 * * *$ & $0.1687 * * *$ & $0.0690 *$ \\
\hline ROA & $-3.6277 * * *$ & $-9.1308 * * *$ & $-8.6605 * * *$ & $-6.5797 * * *$ & $-2.8697 * *$ \\
\hline MTB & $0.0359 * * *$ & $0.1691 * * *$ & $0.1990 * * *$ & $0.0762 * * *$ & $0.0289 *$ \\
\hline CAPIRAL & 0.0457 & -0.9758 & -0.6082 & -0.7042 & 0.1437 \\
\hline TRADING & 0.2181 & $2.3964 *$ & $3.8364 * *$ & $2.3925^{*}$ & 0.6442 \\
\hline LOAN & $0.2384 * *$ & $0.8391 * * *$ & $1.4981 * * *$ & $1.1749 * * *$ & $0.4967 * * *$ \\
\hline OFFBSRISK & 0.0029 & 0.015 & 0.0137 & 0.0043 & 0.0098 \\
\hline SIGMA & $-1.3934 * * *$ & $-5.0965 * * *$ & $-7.2799 * * *$ & $-5.1013 * * *$ & $-2.0613 * * *$ \\
\hline RET & $8.5342 * * *$ & $32.4974 * * *$ & $49.9995 * * *$ & $35.8289 * * *$ & $13.5071 * * *$ \\
\hline Constant & $-2.1653 * * *$ & $-6.5473 * * *$ & $-15.7041 * * *$ & $-10.9906^{* * *}$ & $-2.9925^{* *}$ \\
\hline FF & YES & YES & YES & YES & YES \\
\hline YF & YES & YES & YES & YES & YES \\
\hline Observations & 6619 & 6619 & 6619 & 6619 & 6619 \\
\hline Adj. $R^{2}$ & 0.0521 & 0.0887 & 0.101 & 0.0886 & 0.386 \\
\hline
\end{tabular}

Table 2. Bank Opacity and Crash Risk

For all five measures of crash risk, we find loan to be significantly positively related to the crash risk of a BHC (see Table 2 columns 1-5). For four measures of crash risk including EXTRASIGMA, NCSKEW, DUVOLT and COUNT, we find trading assets to have a significant positive relationship with crash risk (see Table 2 columns 2-5). The only measure of crash risk that is not significantly associated with trading assets is CRASH (see Table 2 column 1).

\subsection{Bank Opacity, CEO Compensation and Crash Risk}

To account for the effect of equity-based CEO pay on crash risk, we include in the regression the incentive ratio created by Bergstresser and Philippon (2006)

CRASHRISK $_{t}=\beta_{0}+\beta_{1}$ Size $_{t-1}+\beta_{2}$ MTB $_{t-1}+\beta_{3}$ ROA $_{t}+\beta_{4}$ LOAN $_{t}+\beta_{5}$ TRADING $_{t}+\beta_{6}$ INCENTIVE_OPT $_{t-1}+\beta_{7}$ INCENTIVE_STK ${ }_{t-1}+\beta_{8}$ SIGMA $_{t-1}+\beta_{9} R E T_{t-1}+\beta_{10}$ CAPITAL $_{t}+\beta_{11}$ OFFBSRISK $_{t}+F F+Y F+\varepsilon_{t}$

Where INCENTIVE_OPT is the incentive ratio for options and INCENTIVE_STK is the incentive ratio for stock holdings, as defined in section 4.2. 
Table 3. CEO Equity-based Compensation, Bank Opacity and Crash Risk

\begin{tabular}{llllll}
\hline & CRASH & EXTRASIGMA & NCSKEW & DUVOLT & COUNT \\
\hline SIZE & 0.0419 & 0.2293 & 0.2583 & 0.1653 & 0.0553 \\
ROA & -1.3964 & -6.4201 & -6.8334 & -4.1989 & -0.1612 \\
MTB & -0.0036 & 0.1009 & 0.1247 & 0.027 & -0.002 \\
CAPITAL & -0.3161 & 0.5068 & 2.6749 & 1.5372 & -0.3483 \\
TRADE & 0.3062 & 1.9793 & 0.6749 & 0.8455 & -0.3847 \\
LOAN & $0.4931^{* *}$ & $1.7655^{* *}$ & $2.6643^{* * *}$ & $2.2593^{* * *}$ & 0.596 \\
OFFBSRISK & -0.0102 & -0.0119 & -0.0196 & -0.0055 & -0.0143 \\
SIGMA & $-2.9584^{* * *}$ & $-9.2066^{* * *}$ & $-12.6005^{* * *}$ & $-8.3543^{* * *}$ & $-3.9353^{* * *}$ \\
RET & $6.3347^{* *}$ & $28.7039^{* * *}$ & $49.5371^{* * *}$ & $35.5714^{* * *}$ & $15.6436^{* * *}$ \\
OPT_INCENTIVE & 0.0232 & -0.0894 & -0.4153 & -0.4093 & -0.0112 \\
STK_INCENTIVE & 0.1593 & 0.5534 & 0.6026 & 0.4251 & 0.0514 \\
Constant & -0.0772 & -1.4541 & -4.4623 & -2.9349 & -0.3838 \\
\hline FF & YES & YES & YES & YES & YES \\
YF & YES & YES & YES & YES & YES \\
Observations & 1273 & 1273 & 1273 & 1273 & 1273 \\
Adj. R ${ }^{2}$ & 0.0855 & 0.1286 & 0.1311 & 0.1178 & 0.3327 \\
\hline
\end{tabular}

Our results suggest that neither INCENTIVE_OPT nor INCENTIVE_STK is significantly related to any of our measures of crash risk (see table 3 columns 1-5). The results are consistent with Fahlenbrach and Stulz (2011)'s argument that equity-based pay does not give managers incentives to inflate short term performance at the cost of long term performance.

\subsection{Endogeneity of Bank Opacity}

Our results suggest that the opacity of bank assets can lead to higher crash risk. However, an alternative explanation is also plausible, that is, bank opacity and crash risk are driven by the same variables that are missing from our analysis.

To address this endogeneity problem, we introduce a simultaneous equations model, and we use the three-stage least square (3SLS) technique to estimate it using one (or more) instrumental variables proxy for each of the endogenous variables. The model is described as follows

$$
\begin{aligned}
& \text { CRASHRISK }_{i}=\beta_{0}+\beta_{1} \text { SIZE }_{j}+\beta_{2} \text { LOAN }_{j}+\beta_{3} \text { TRADING }_{j}+\beta_{4} \text { MTB }_{i}+\beta_{5} \text { ROA }_{i}+\beta_{6} \text { CAPITAL }_{j}+Y F+F F+\varepsilon_{i}(12) \\
& \text { LOAN }_{j}=\alpha_{0}+\alpha_{1} \text { SIZE }_{j}+\alpha_{2} \text { CRASHRISK }_{i}+\alpha_{3} \text { TRADING }_{j}+\alpha_{4} \text { Larg } \text { etTimeDeposits }_{j}+\alpha_{5} \text { FedFundRate } \\
& +Y F+F F+\varepsilon_{j}^{\prime}(13) \\
& \text { TRADING }_{j}=\delta_{0}+\delta_{1} \text { SIZE }_{j}+\delta_{2} \text { CRASHRISK }_{i}+\delta_{3} \text { LOAN }_{j}+\delta_{4} \text { InterestIncome }_{j}+Y F+F F+\varepsilon_{j}(14)
\end{aligned}
$$

A good instrumental variable should be highly correlated with the regressor it serves as an instrument for but unrelated to the error terms of the regression equation (Angrist and Krueger, 2001). We choose our instruments according to these criteria. First, we use the ratio of large time deposits to total assets (LargeTimeDeposits) and fed funds rate (FedFundRate) as instruments for the share of loans in total assets, one of our measures for opacity. Kishan and Opiela (2000) and Romer and Romer (1990) suggest that large time deposits are among the major determinants of total loans, while Bernanke and Blinder (1992) find that fed funds rate transmits monetary policy by affecting the level of bank loans. Secondly, we use the lagged value of interest income (InterestIncome) as the instrumental variable for the share of trading assets in total assets, another measure of opacity used in this paper. This can be defended on the grounds that when the traditional interest income of banks declines, they switch to non-interest income activities such as trading (Stiroh, 2004). 
Table 4 presents the 3SLS parameter estimates of the model. Each panel of Table 4 is for a distinct measure of crash risk (i.e. CRASH, EXTRASIGMA, NCSKEW, DUVOLT, and COUNT respectively). The key parameters of interest in this model are the coefficients of LOAN and TRADING as determinants of crash risk. The findings are consistent with what we find earlier in the basic model (equation 10). EXTRASIGMA, NCSKEW and DUVOLT are all positively related to LOAN (Column 1 for panels 2-4 of table 4). CRASH and EXTRASIGMA are positively related to TRADING (Column 1 for panels 1-2 of table 4). The only measure of crash risk that we do not find to be significantly related to bank opacity is COUNT. The 3SLS results suggest that an increase in opaque assets leads to a higher crash risk.

The coefficients of crash risk in the LOAN and TRADING equations (columns 2 and 3 for all panels of table 4) are both negative and statistically significant at the $1 \%$ level, suggesting that BHCs with higher crash risk tend to make fewer loans and engage in fewer trading activities. Hence, the association between crash risk and asset opacity is bi-directional in nature. Therefore, this endogeneity must be accounted for in modeling crash risk. The coefficient estimates for LOAN and TRADING are considerably larger in magnitude in this model, than we find earlier in our basic single-equation model. This is an indication that if we do not account for endogeneity, the coefficient estimates can be highly distorted.

Table 4. 3SLS Bank Opacity and Crash Risk

This table reports the results for the following 3SLS model:

$$
\begin{aligned}
& \text { CRASHRISK }_{i}=\beta_{0}+\beta_{1} \text { SIZE }_{j}+\beta_{2} \text { LOAN }_{j}+\beta_{3} \text { TRADING }_{j}+\beta_{4} \text { MTB }_{i}+\beta_{5} \text { ROA }_{i}+\beta_{6} \text { CAPITAL }_{j}+Y F+F F+\varepsilon_{i} \\
& \text { LOAN }_{j}=\alpha_{0}+\alpha_{1} \text { SIZE }_{j}+\alpha_{2} \text { CRASHRISK }_{i}+\alpha_{3} \text { TRADING }_{j}+\alpha_{4} \text { Larg } \text { etTimeDeposits }_{j}+\alpha_{5} \text { FedFundRate } \\
& +Y F+F F+\varepsilon_{j}^{\prime} \\
& \text { TRADING }_{j}=\delta_{0}+\delta_{1} \text { SIZE }_{j}+\delta_{2} \text { CRASHRISK }_{i}+\delta_{3} \text { LOAN }_{j}+\delta_{4} \text { InterestIncome }_{j}+Y F+F F+\varepsilon_{j}
\end{aligned}
$$

Panel 1

\begin{tabular}{llll}
\hline & \multicolumn{1}{c}{ CRASH } & \multicolumn{1}{c}{ LOAN } & TRADE \\
\hline LOAN & 0.3586 & & $-.1004^{* * *}$ \\
TRADE & $1.1971^{* *}$ & $-1.4161^{* * *}$ & \\
SIZE & $-0.0037^{* *}$ & $-0.0040^{* * *}$ & $0.002^{* * *}$ \\
CRASH & & $-0.0956^{* * *}$ & $-.0148^{* * *}$ \\
LargeTimeDeposit & & $0.2830^{* * *}$ & \\
InterestIncome & & & $0.0000^{* * *}$ \\
FedFundsRate & & -0.7683 & \\
ROA & $-1.6676^{* * *}$ & & \\
MTB & $0.0567^{* * *}$ & & \\
CAPITAL & 0.3133 & & \\
OFFBSRISK & $0.0163^{* *}$ & & \\
SIGMA & $-0.8231^{* * *}$ & & \\
RET & $5.2517^{* * *}$ & & $.0416^{* * *}$ \\
Cons & 0.0098 & $.6954^{* * *}$ & 0.2199 \\
\hline $\boldsymbol{R}^{2}$ & 0.0324 & 0.0795 & 480 \\
$\boldsymbol{C H I}$ & 328.48 & 968 & 0 \\
$\boldsymbol{P}$ value & 0 & 0 & 6478 \\
Observations & 6478 & 6478 & \\
\hline
\end{tabular}


Panel 2

\begin{tabular}{|c|c|c|c|}
\hline & EXTRASIGMA & LOAN & TRADE \\
\hline LOAN & $1.8385^{* *}$ & & $-.0990 * * *$ \\
\hline TRADE & $3.0460 *$ & $-1.4905 * * *$ & \\
\hline SIZE & .0105 & $-.0032 * *$ & $.0021 * * *$ \\
\hline EXTRASIGMA & & $-.0278 * * *$ & $-.0041 * * *$ \\
\hline LargeTimeDeposit & & $.2879 * * *$ & \\
\hline InterestIncome & & & $0.0000^{*}$ \\
\hline FedFundsRate & & -.7379 & \\
\hline ROA & -2.3985 & & \\
\hline MTB & $.2021 * * *$ & & \\
\hline CAPITAL & .4097 & & \\
\hline OFFBSRISK & $.0331 *$ & & \\
\hline SIGMA & $-3.3710 * * *$ & & \\
\hline RET & $21.0628 * * *$ & & \\
\hline _cons & $1.4597 * *$ & $.7412 * * *$ & $.0480 * * *$ \\
\hline$R^{2}$ & 0.0562 & 0.1073 & 0.2410 \\
\hline CHI & 571 & 1012 & 488 \\
\hline$P$ value & 0 & 0 & 0 \\
\hline Observations & 6478 & 6478 & 6478 \\
\hline
\end{tabular}

Panel 3

\begin{tabular}{|c|c|c|c|}
\hline & NCSKEW & LOAN & TRADE \\
\hline LOAN & $2.2725^{* *}$ & & $-.1000 * * *$ \\
\hline TRADE & -0.3975 & $-1.5768 * * *$ & \\
\hline SIZE & $0.0741 * * *$ & -0.0018 & $.0023 * * *$ \\
\hline NCSKEW & & $-.0237 * * *$ & $-.0030 * * *$ \\
\hline LargeTimeDeposits & & $.2848 * * *$ & \\
\hline InterestIncome & & & $0.0000 *$ \\
\hline FedFundsRate & & -.7350 & \\
\hline ROA & 2.624 & & \\
\hline MTB & $0.2131 * * *$ & & \\
\hline CAPITAL & -0.0152 & & \\
\hline OFFBSRISK & $0.0564 * *$ & & \\
\hline SIGMA & $-5.0066 * * *$ & & \\
\hline \multicolumn{4}{|l|}{ RET } \\
\hline & $33.0198 * * *$ & & \\
\hline _cons & $-2.1807 * * *$ & $.6505 * * *$ & $.0359 * * *$ \\
\hline$R^{2}$ & 0.0715 & 0.0740 & 0.2369 \\
\hline CHI & 646 & 987 & 496 \\
\hline$P$ value & 0 & 0 & 0 \\
\hline Observations & 6478 & 6478 & 6478 \\
\hline
\end{tabular}


Panel 4

\begin{tabular}{|c|c|c|c|}
\hline & DUVOLT & LOAN & TRADE \\
\hline LOAN & $1.6124 * *$ & & $-.0969 * * *$ \\
\hline TRADE & -.3253 & $-1.5418 * * *$ & \\
\hline SIZE & $.0639 * * *$ & -.0019 & $.0022 * * *$ \\
\hline DUVOLT & & $-.0323 * * *$ & $-.0033 * * *$ \\
\hline LargeTimeDeposits & & $.2882 * * *$ & \\
\hline InterestIncome & & & $0.0000 * * *$ \\
\hline FedFundsRate & & -.7250 & \\
\hline ROA & 1.2195 & & \\
\hline MTB & $.1054 * * *$ & & \\
\hline CAPITAL & -.0605 & & \\
\hline OFFBSRISK & $.0495 * * *$ & & \\
\hline SIGMA & $-3.6633 * * *$ & & \\
\hline \multicolumn{4}{|l|}{ RET } \\
\hline & $24.0285 * * *$ & & \\
\hline _cons & $-1.7210 * * *$ & $.6482 * * *$ & $.0338 * * *$ \\
\hline$R^{2}$ & 0.0544 & 0.0813 & 0.2558 \\
\hline CHI & 523 & 995 & 483 \\
\hline$P$ value & 0 & 0 & 0 \\
\hline Observations & 6478 & 6478 & 6478 \\
\hline
\end{tabular}

\section{Conclusion}

Banks are considered more opaque than non-bank firms due to the fact that bank loans are privately negotiated and some bank assets are intrinsically complex and difficult to value. We look at the main sources of bank opacity - loans and trading assets and explore their relationship with stock price crash risk. We find that banks with greater shares of loans and/or trading assets in total assets tend to have higher crash risk. The results are robust to different measures of crash risk and different model specifications. We also look at the impact of CEO equity-based pay on crash risk because equity-based pay has been blamed for giving managers incentives to engage in short-termism activities, which could have been a cause for the financial crisis in 2007-2009. We do not find incentives from CEO equity-based pay to be significantly related to any of our measures of crash risk.

Our results have important policy implications. First, our findings that loans and trading assets lead to higher crash risk suggest that it is important that more effective regulations be enacted to enhance the transparency of loans and trading assets. Secondly, our findings that CEO equity-based pay is not significantly related to crash risk could suggest that equity-based pay does not necessarily lead to more short-termism activities by managers. Therefore, in their attempts to reform managerial compensation in the U.S., regulators and shareholder activists should bear in mind that the argument equity-based pay leads to higher risk is not well grounded.

\section{References}

Angrist, J. D. \& A. B. Krueger. (2001). Instrumental variables and the search for identification: From supply and demand to natural experiments, Journal of Economic Perspectives, 15, 69-85.

An, H. \& T. Zhang. (2013). Stock price synchronicity, crash risk, and institutional investors. Journal of Corporate Finance, 21, 1-15.

Bebchuk, L.A. (2009). Written testimony, hearing on compensation structures and systematic risk, Committee on Financial Services, U.S. House of Representatives, June 11.

Benmelech, E., E. Kandel, P. Veronesi. (2010). Stock-based compensation and CEO (dis)incentives. Quarterly Journal of Economics, 125 (4), 1769-1820. http://dx.doi.org/10.1162/qjec.2010.125.4.1769 
Bergstresser, D., T. Philippon. (2006). CEO incentives and earnings management. Journal of Financial Economics, 80 (3), 511-529. http://dx.doi.org/10.1016/j.jfineco.2004.10.011

Bernanke, B. S. \& A. S. Blinder. (1992). The Federal funds rate and the channels of monetary transmission, American Economic Review, 82, 901-921.

Bleck, A., X. Liu. (2007). Market transparency and the accounting regime. Journal of Accounting Research, 45(2), 229-256. http://dx.doi.org/10.1111/j.1475-679X.2007.00231.x

Bradshaw, M. T. , A.P. Hutton, A.J. Marcus \& H. Tehranian. (2010). Opacity, crash risk, and the option smirk Ccurve. http://dx.doi.org/10.2139/ssrn.1640733

Chen, J.; Hong, H.; Stein, J. C. (2001). Forecasting crashes: trading volume, past returns, and conditional skewness in stock prices. Journal of Financial Economics, 61(3), 345-381.

Cheng, Q., T.D. Warfield. (2005). Equity incentives and earnings management. Accounting Review, 80, 441-476. http://dx.doi.org/10.2308/accr.2005.80.2.441

Core, J., W. Guay. (2002). Estimating the value of employee stock option portfolios and their sensitivities to price and volatility, Journal of Accounting Research, 40 (3), 613-630. http://dx.doi.org/10.1111/1475-679X.00064

Dechow, P. M., R. G. Sloan \& A. P. Sweeney. (1996). Causes and consequences of earnings manipulation: an analysis of firms subject to enforcement actions by the SEC. Contemporary Accounting Research, 13(1), 1-36. http://dx.doi.org/10.1111/j.1911-3846.1996.tb00489.x

Degeorge, F., J. Patel, R. Zeckhauser. (1999). Earnings management to exceed thresholds. Journal of Business, 72 (1), 1-33. http://dx.doi.org/10.1086/209601

Fahlenbrach, R., R. M. Stulz. (2011). Bank CEO incentives and the credit crisis, Journal of Financial Economics, 99(1), 11-26. http://dx.doi.org/10.1016/j.jfineco.2010.08.010

Flannery, M. J., H.K.Simon, \& M. Nimalendran. (2004). Market evidence on the opaqueness of banking firms' assets, Journal of Financial Economics, 71, 419-460. http://dx.doi.org/10.1016/S0304-405X(03)00185-5

Greenspan A. (1996). Remarks at Financial Markets Conference of the Federal Reserve Bank of Atlanta, Coral Gabels, FL, February 23, 1996.

Hutton, A. P., A. J. Marcus \& H. Tehranian. (2009). Opaque financial reports, $\mathbf{R}^{2}$, and crash risk. Journal of Financial Economics, 94 (1), 67-86. http://dx.doi.org/10.1016/j.jfineco.2008.10.003

Jin, L., S. C, Myers. (2006). R 2 around the world: new theory and new tests. Journal of Financial Economics, 79(2), 257-292. http://dx.doi.org/10.1016/j.jfineco.2004.11.003

Jones, J. S., Lee, Y. Wayne, T. J. Yeager. (2013). Valuation and systemic risk consequences of bank opacity, Journal of Banking \& Finance, 37(3), 693-706. http://dx.doi.org/10.1016/j.jbankfin.2012.10.028

Jones, J. S., W.Y. Lee, T.J. Yeager. (2012). Opaque banks, price discovery, and financial instability. Journal of Financial Intermediation, 21(3), 383-408. http://dx.doi.org/10.1016/j.jfi.2012.01.004

Kim, J. B., Y. Li, L. Zhang. (2011a). CFOs versus CEOs: equity incentives and crashes. Journal of Financial Economics, 101(3), 713-730. http://dx.doi.org/10.1016/j.jfineco.2011.03.013

Kim, J. B., Y. Li, L. Zhang. (2011b). Corporate tax avoidance and stock price crash risk: firm-level analysis. Journal of Financial Economics, 100 (3), 639-66. http://dx.doi.org/10.1016/j.jfineco.2010.07.007

Kishan, R.P., \& P.O. Timothy. (2000). Bank size, bank capital, and the bank lending channel, Journal of Money, Credit and Banking, 32, 121-141. http://dx.doi.org/10.2307/2601095

Morgan, D. P. (2002). Rating banks: risk and uncertainty in an opaque industry. American Economic Review, 92 (4), 874-888. http://dx.doi.org/10.1257/00028280260344506

Romer, C. D., \& D. H. Romer. (1990). New evidence on the monetary transmission mechanism, Brookings Papers on Economic Activity, 21, 149-214. http://dx.doi.org/10.2307/2534527

Stiroh, K. J. (2004). Diversification in banking: is noninterest income the answer? Journal of Money, Credit \& Banking, 36, 853-883. http://dx.doi.org/10.1353/mcb.2004.0076 